\title{
Memorial tribute to astrobiology pioneers Dr. David S. Mckay and academician Georgy A. Zavarzin
}

\section{Alexei Rozanov, Sergei Rozhnov, Elena Pikuta, Richard Hoover}

Alexei Yu. Rozanov, Sergei V. Rozhnov, Elena V. Pikuta, Richard B. Hoover, "Memorial tribute to astrobiology pioneers Dr. David S. Mckay and academician Georgy A. Zavarzin," Proc. SPIE 8865, Instruments, Methods, and Missions for Astrobiology XVI, 886502 (26 September 2013); doi: $10.1117 / 12.2029404$

Event: SPIE Optical Engineering + Applications, 2013, San Diego, California, United States 


\title{
Memorial Tribute to Astrobiology Pioneers Dr. David S. McKay and Academician Georgy A. Zavarzin
}

\author{
Alexei Yu. Rozanov \\ Director, Astrobiology Institute, \\ Joint Institute for Nuclear Research, (RAS) \\ Dubna, Russian Federation \\ E-mail: Aroza@paleo.ru; \\ Sergei V. Rozhnov \\ Director, Borissiak Paleontological Institute, (RAS) \\ Moscow, Russian Federation \\ E-mail: Rozhnov@paleo.ru; \\ Elena V. Pikuta \\ Athens State University, Athens, Alabama USA \\ evpikuta@my.athens.edu \\ Richard B. Hoover \\ Buckingham Centre for Astrobiology, University of Buckingham, \\ Buckingham, MK18 1EG, United Kingdom \\ and \\ Athens State University, Athens, Alabama USA \\ e-mail: Entogonia@aol.com
}

\begin{abstract}
During the past two years, the world has lost two great pioneers of the field of Astrobiology-Dr. David Stewart McKay who worked at the NASA-Johnson Space Center in Houston, Texas, USA and Academician Georgy Alexandrovich Zavarzin of the Institute of Microbiology of the Russian Academy of Sciences and Professor of the Moscow State University in Moscow, Russia. The Volume of the Proceedings of the 2013 SPIE Instruments, Methods, and Missions for Astrobiology XVI is dedicated to the memory of these great scientists. We remember our dear friends and review some of their many important contributions to Planetary Science, Geology, Meteoritics, Microbiology and Astrobiology.
\end{abstract}

KEYWORDS: Dr. David S. McKay, Academician Georgy A. Zavarzin, Lunar Dust, Meteorites, Mars, Bacteria, Cyanobacteria, Lithotrophic Microorganisms, Microbial Extremophiles

Instruments, Methods, and Missions for Astrobiology XVI, edited by Richard B. Hoover,

Gilbert V. Levin, Alexei Yu. Rozanov, Nalin C. Wickramasinghe, Proc. of SPIE Vol. 8865

886502 @ 2013 SPIE · CCC code: 0277-786X/13/\$18 - doi: 10.1117/12.2029404

Proc. of SPIE Vol. $8865886502-1$ 


\section{DR. DAVID STEWART McKAY}

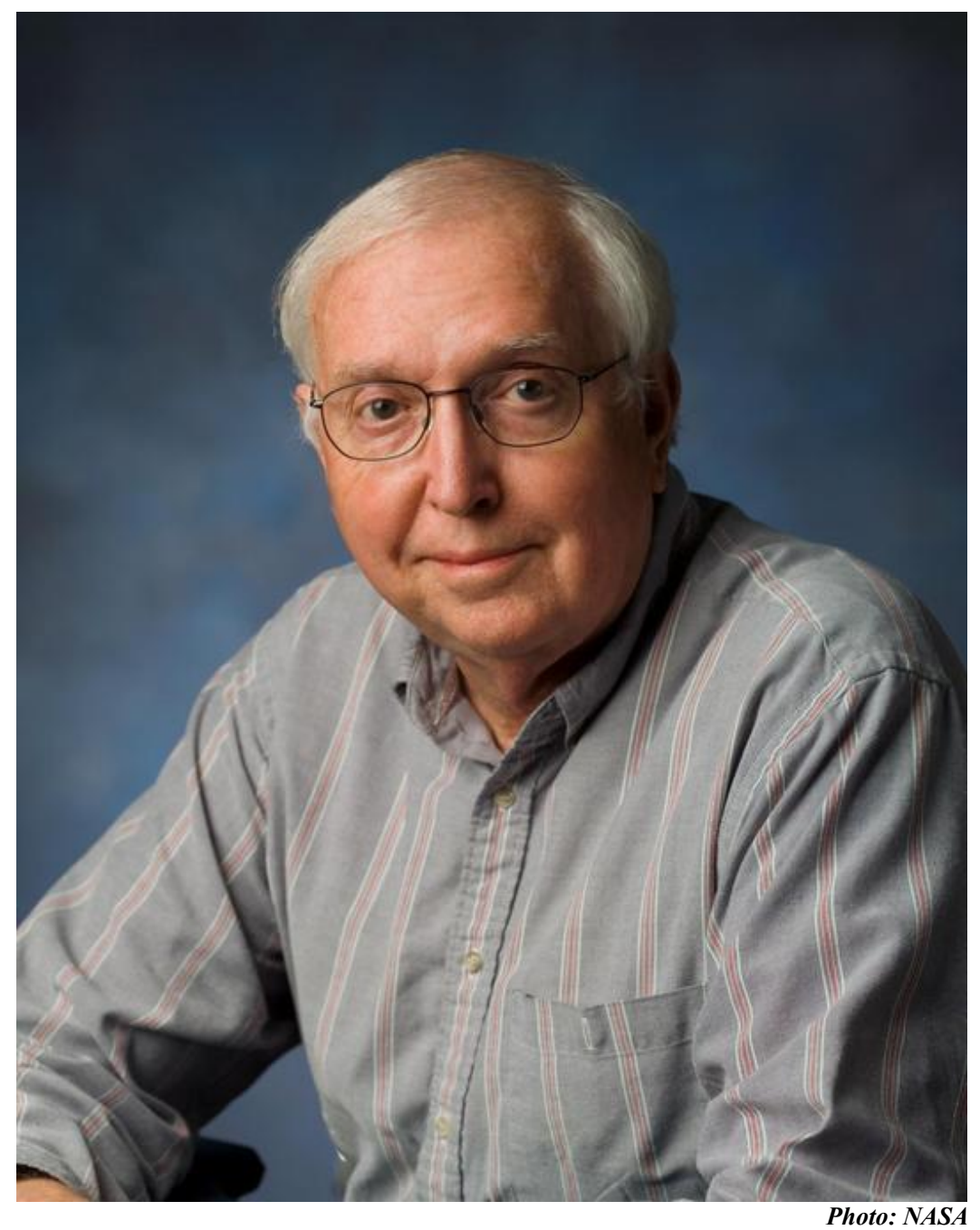

September 25, 1936 - February 20, 2013

David Stewart McKay is perhaps the best known of all Astrobiologists. On August 6, 1996, Dr. McKay and his coworkers published their seminal paper in Science entitled: "Search for past life on Mars: Possible relic biogenic activity in Martian meteorite ALH84001." This paper presented independent lines of evidence (carbonate globules, PAH's, biogenic magnetites and possible nanofossils) detected in the Allan Hills meteorite ALH84001 suggesting that microbial life existed on ancient Mars. It was hypothesized that the ALH84001 stone was shocked and fractured by meteoroid impacts on the surface of Mars $\sim 3.9$ to 4.0 billion years ago when Mars was warmer and wetter than present.

Dr. McKay and his team presented Scanning Electron Microscope images of putative nanofossils with simple morphologies and a suite of associated biomarkers. They advanced the hypothesis that nanobacteria had long ago invaded fractures in the rock and by their biogenic activity produced the chemical and mineral biomarkers that were detected. Although this interpretation remains controversial, their paper had an immediate and profound effect on Science resulting in the formation of the modern field of Astrobiology. It stimulated support for research in planetary science, microfossils, bacterial paleontology, meteoritics, microbial extremophiles and the origin and evolution of life and the formation of the biosphere. Many countries initiated important new programs to develop rovers and robotic missions to explore Mars, Phobos, comets, and icy moons of Jupiter and Saturn. The search for evidence of extraterrestrial water, biogenic elements, biomolecules, biosignatures and microfossils in meteorites was resumed after it 
had been abandoned in the wake of the "organized elements" controversy of the early 1960's. Study of the physical, chemical and environmental limits of life and the search for extra-solar planets, water and biogenic elements elsewhere in the cosmos gained enhanced public interest and funding support within NASA, ESA, the Russian Academy of Sciences and Companies and Academic Institutions in many countries.

Dr. David S. McKay was born on September 25, 1936 in Titusville, Pennsylvania. He received his Bachelor of Science degree in Geology in 1958 from Rice University in Houston and his M.S. degree in geochemistry from the University of California, Berkeley. He worked for the Exxon Corporation as a field geophysicist prior to returning to Rice University to complete his doctorate in geology in 1964. He joined the National Aeronautics and Space Administration in 1965 accepting a post at the NASA Johnson Space Center to work on the Apollo Lunar Missions. David Stewart McKay died on February 20, 2013. At the time of his death, he was still employed as Chief Scientist for Astrobiology in the ARES Office at the NASA Johnson Space Center.

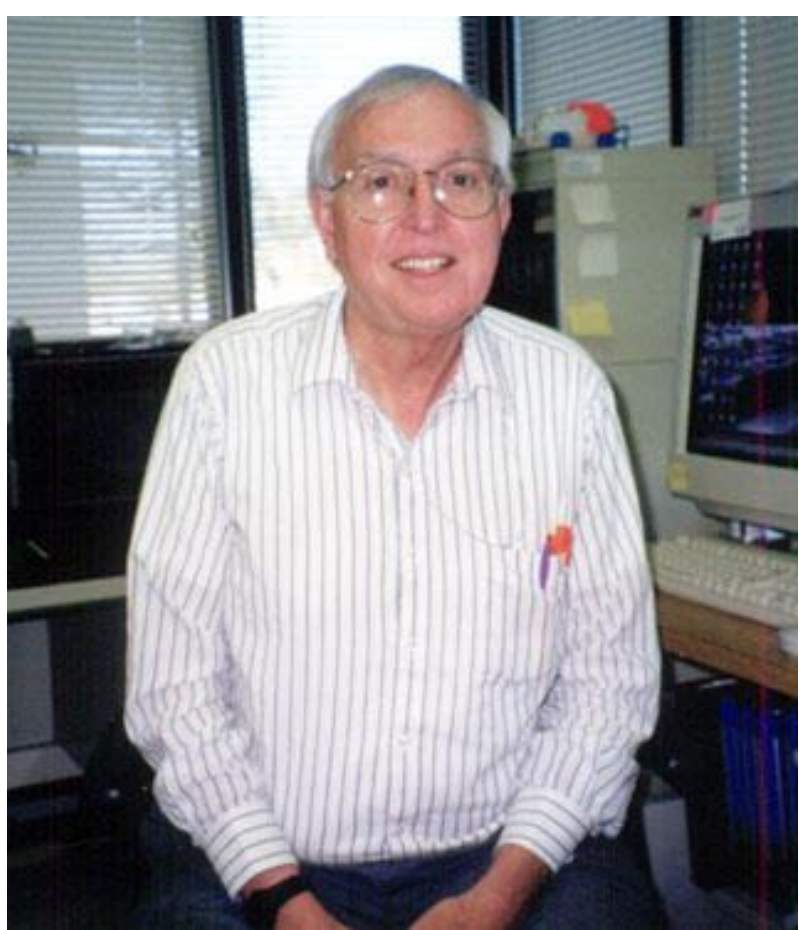

a.

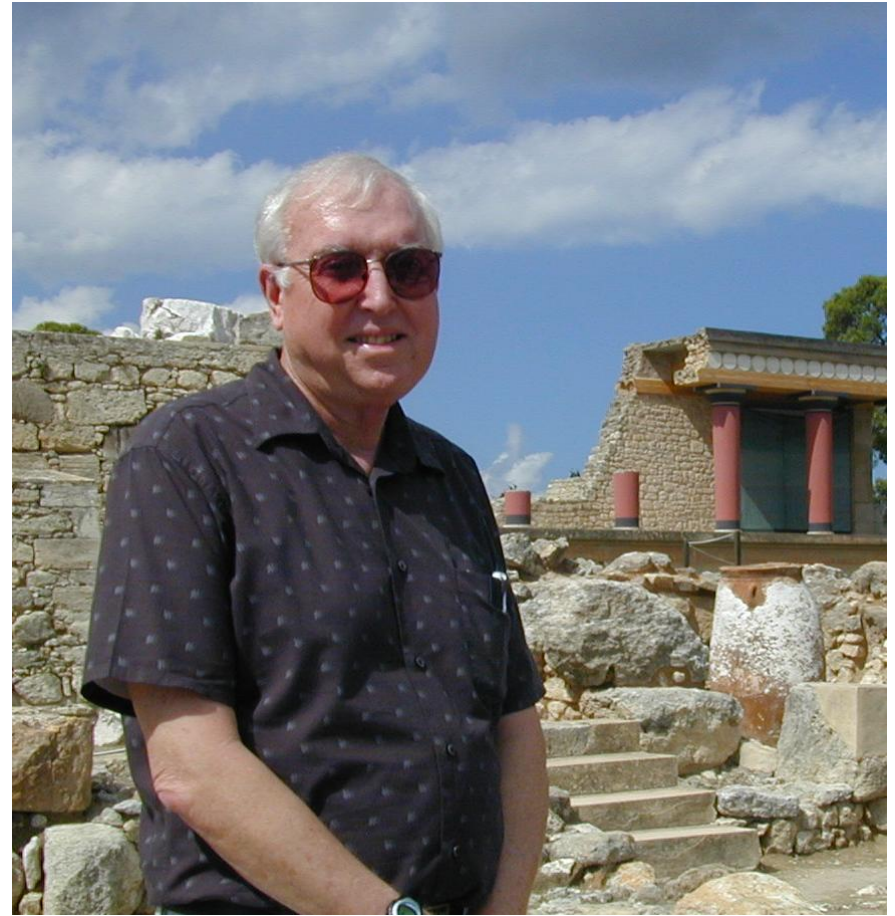

b.

Fig. 1. Dr. David S. McKay a. in his office at the NASA Johnson Space Center, Houston, Texas and b. visiting the Palace of Minos in Knossus, Crete, Greece during the NATO Advanced Study Institute on Perspectives in Astrobiology.

Photos: a. G. Jeffrey Taylor; b. Richard B. Hoover

Dr. David McKay had a distinguished career at NASA/JSC that spanned almost five decades of brilliant, creative important contributions to the American Space Program and to planetary science. Early in his career, he was chief trainer for the Apollo 11 Lunar Astronauts Neil Armstrong and Buzz Aldrin during their last geology field trip in West Texas. Dr. McKay was the only geologist in the Apollo Mission Control Room at NASA/JSC on July 20, 1969 when Armstrong and Aldrin conducted their historic first walk on the moon by man. Dave McKay developed great expertise as an microscopist and became highly skilled in Optical, Scanning Electron Microscopy (SEM) and Transmission Electron Microscopy (TEM) and Electron and Ion Microprobes. Dave used these diverse tools to conduct detailed analyses of the returned samples of lunar dust and rocks and meteorites from Mars. He conducted visible light and SEM analysis of the Apollo 15 green dust and the strange orange soil sample (74220) (Fig. 2.a.) discovered at Shorty Crater on the moon during the Apollo 17 mission. ${ }^{2,3}$ This work established that the orange and black particles (Fig. 2.b.) of the orange soil had the same chemical compositions and were deposits of pyroclastic origin. ${ }^{4-6}$ 
In 1993, Lindsay Keller and David McKay used transmission electron microscopy (TEM to investigate lunar dust returned during the Apollo Program. They demonstrated nanophase metallic iron beads associated with silica-rich glassy rims on individual mineral grains. They showed that these nanophase iron grains were located within vapor deposited grain coatings with the vapor produced by impacts of micrometeorites and/or sputtering by the solar wind. ${ }^{7}$ Dave also explored vapor deposition phenomena in the Apollo lunar dust samples ${ }^{8}$, the size distribution of lunar dust grains ${ }^{9}$, and the toxicity of lunar dust $\mathrm{t}^{10,11}$ and studied space weathering on the moon. ${ }^{12,13}$ in preparation for long duration manned missions to the Moon and to Mars. They even considered the possibility of bio-weathering of lunar and martian rocks by cyanobacteria. ${ }^{14}$

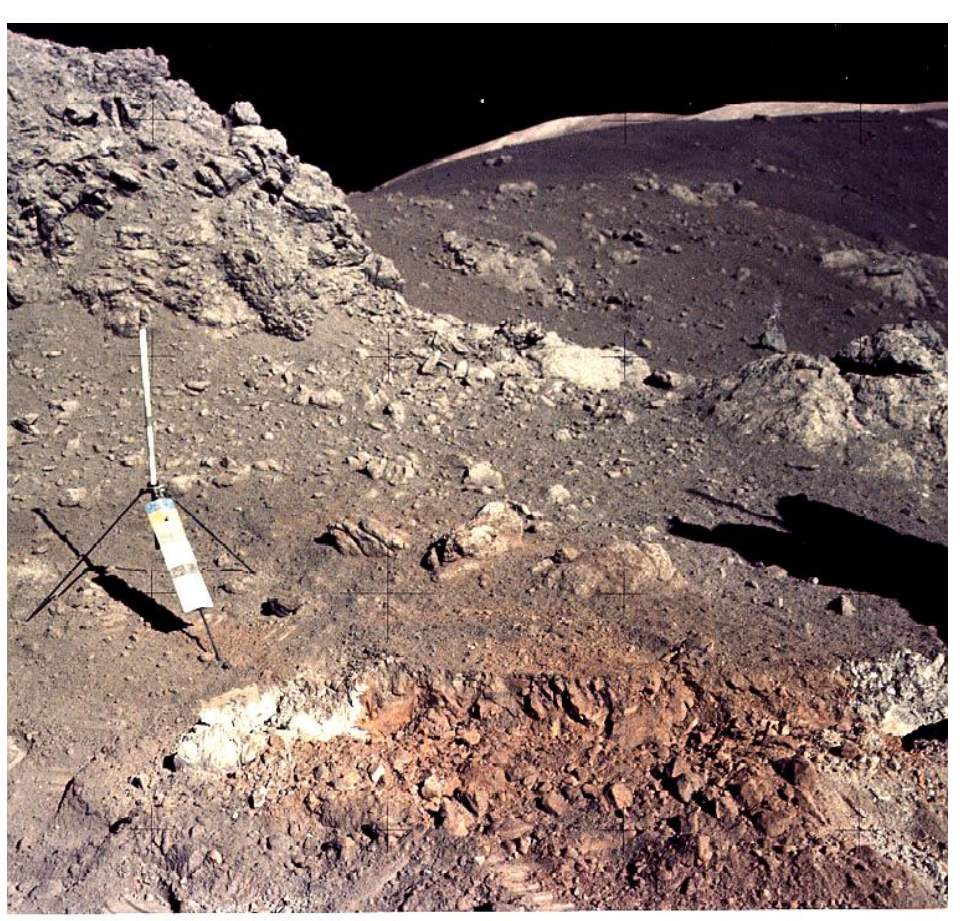

a.

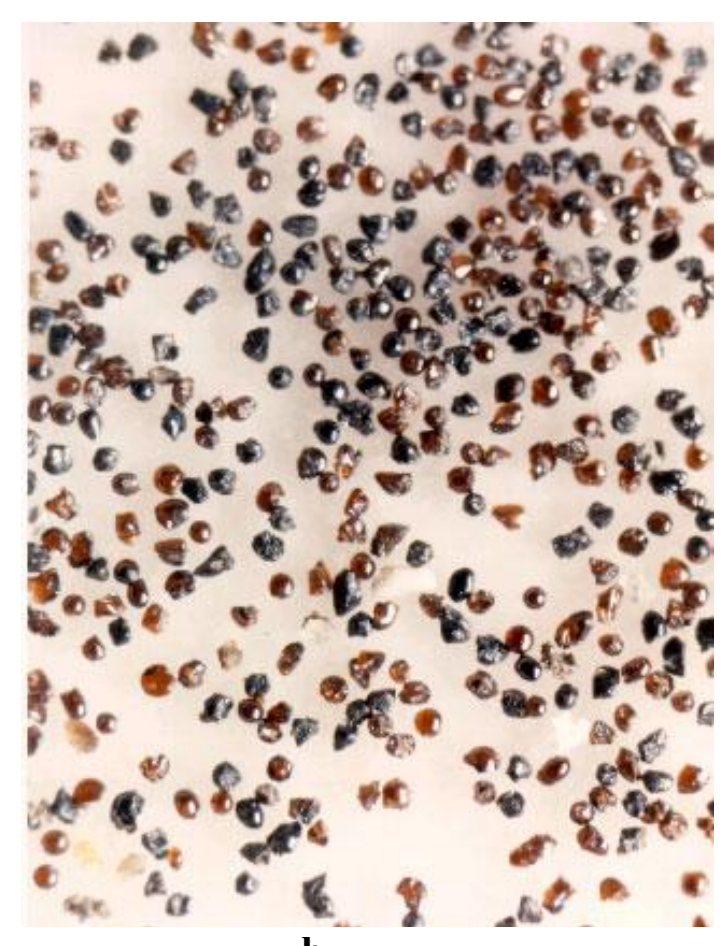

b.

Fig. 2.a. Orange soil in trench dug into rim of Shorty Crater during the Apollo 17 mission and b. Optical microscopy image of 100 micron size orange and black particles in sieved and washed sample (\#74220) of orange soil.

(Photo Courtesy NASA: a. AS17-137-20990 b. S73-15085)

During his career, Dr. David McKay published over 200 scientific papers in peer-reviewed journals and conference proceedings on the subject of lunar dust alone. Many of these papers represented major discoveries:

- discovery of pyroclastic soil deposits indicating lunar volcanism ${ }^{4-6}$

- formation of nanophase iron globules on lunar soil grains ${ }^{7}$

- source of vapor deposition on lunar soil grains ${ }^{7,8}$

- processes on the moon that determine grain size distribution ${ }^{9}$

- toxicity and chemically activated nature of $i n$-situ lunar dust ${ }^{10,11}$

- space weathering on the moon ${ }^{12-14}$

Dr. David McKay became world famous in August, 1996 when NASA announced that his team had detected evidence for possible relic biogenic activity on ancient Mars in the Allan Hills 84001 meteorite (Fig. 3.a,b). ${ }^{1}$ This paper was extensively debated and many critics argued that the putative nanofossils were too small to represent life. However, it is now known that they are larger than many viruses and not dramatically smaller than "ultramicrobacteria". They are comparable in size with "nanobacteria" which have been the subject of biomedical research. although many now contend that these forms are "nanoparticles" are not living. ${ }^{15}$ However, due to their very simple morphology, it is not possible to definitively associate the putative ALH84001"nanofossils" with any known species of archaea or bacteria. 
It is important to recognize that the original McKay et al. ${ }^{1}$ paper drew upon the close association of four different types of biomarkers (PAH's, carbonate globules, biogenic magnetite crystals and nanofossils) in the Mars meteorite ALH84001. Despite the severe criticism, David McKay never veered from his fundamental conclusion that this association of biomarkers was consistent only with relic biogenic activity on Mars and provided evidence for the existence of extraterrestrial life on ancient Mars. Dr. McKay was founder of the Center for the Study of Biomarkers in Astromaterials at the NASA Johnson Space Center in 1998 and Principal Investigator and for this Virtual Astrobiology Institutes that was organized by NASA in response to his Mars meteorite paper. In addition to his studies of meteorites, David McKay did extensive studies on chemical, mineral and morphological biomarkers in ancient terrestrial rocks and SNC meteorites. ${ }^{16}$

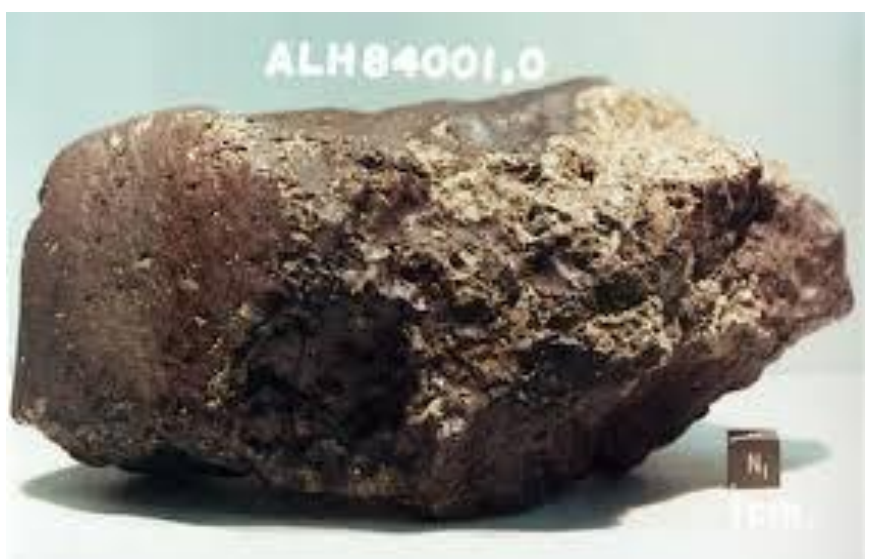

a.

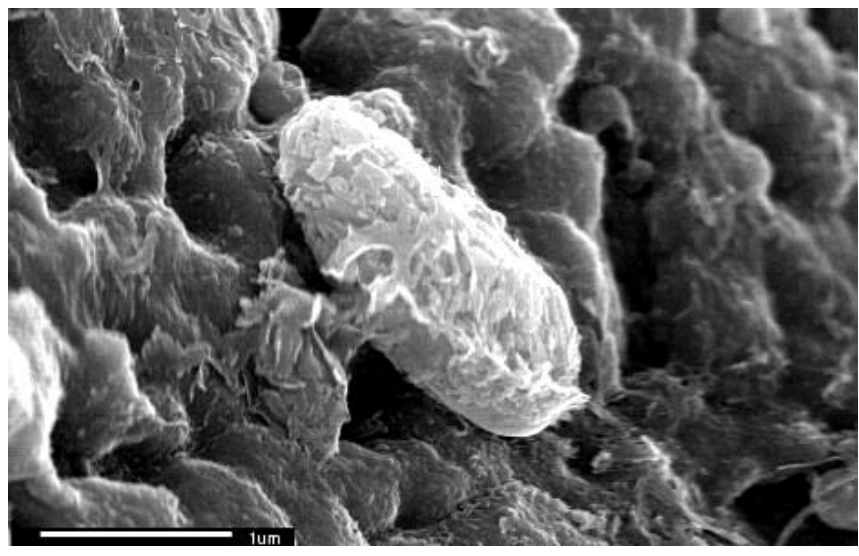

c.

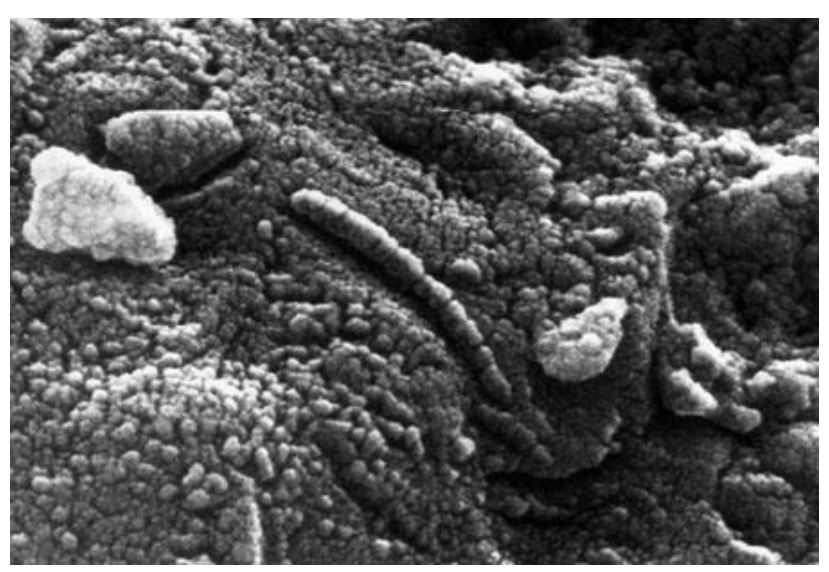

b.

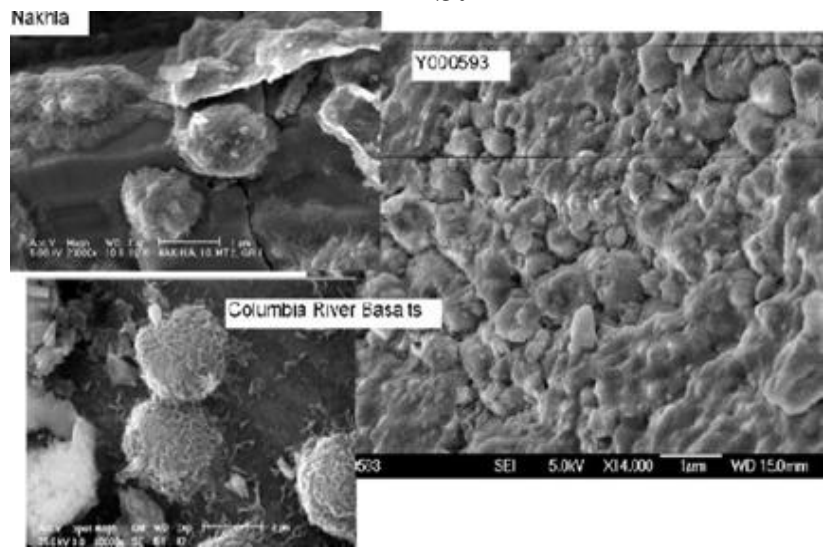

d.

Fig. 3.a. The Mars meteorite ALH84001and b. image of possible nanofossil in ALH84001 c. FESEM images of larger microfossils in the Nakhla meteorite from Mars and d. microfossils in Columbia River Basalts compared with possible microfossils in other SNC meteorites from Mars (Nakhla and Yamato Y000593). (Photos Courtesy: David McKay NASA)

Dr. McKay and his co-workers were able to demonstrate that the magnetite crystals they had found in ALH84001 possessed a unique set of properties that were consistent with biogenic magnetites produced by magnetotactic bacteria on Earth but inconsistent with magnetite crystals produced by abiotic processes. The magnetites in the Allan Hills meteorite were extremely pure iron oxide $\left(\mathrm{Fe}_{3} \mathrm{O}_{4}\right)$ crystals with tightly sorted single domain grain size distribution and elongated along the c-axis of the crystals. They showed that associated with the ALH84001 nanofossils there were truncated hexaoctahedral magnetite crystals. These crystals are known to be produced by magnetotactic bacteria but have no known mechanisms for abiotic origin. ${ }^{17-20}$

In 2001, E. Imre Friedmann and co-workers used stereo Backscattered Scanning Electron Microscopy to show that elongated magnetite crystals within ALH84001were oriented along the crystal axis and arranged in chains and were surrounded by halos that were interpreted as membranes. ${ }^{20}$ These are extremely distinctive features associated with 
chains of magnetosomes in magnetotactic bacteria in Earth. The ALH84001 magnetite crystals exhibited a complex suite of properties that are absolutely unique to magnetites found in magnetotactic bacteria on Earth. Therefore they represented valid biosignatures and provided the best evidence for biogenic remains in the Allan Hills meteorite. Dr. David McKay also provided further evidence for biology on ancient Mars by detecting larger possible microfossils on other SNC meteorites from Mars. These included the Nakhla and Yamato Y000593 meteorites (Fig. 3c. d.). He was able to show that the size and morphologies of large biomorphs detected in these meteorites were very similar to microfossils found in the Columbia River Basalts. ${ }^{21}$

Dr. David S. McKay was the recipient of numerous awards including the Distinguished Texas Scientist Award from the Texas Academy of Science; the NASA Superior Achievement Award for his many contributions to Lunar Science; the NASA Exceptional Scientific Achievement Medal and the Laurels Award from Aviation Week and Space Technology. Dave was a Co-Investigator of The Planetary Society's Phobos LIFE (Living Interplanetary Flight Experiment) project.

The International Astronomical Union (IAU) honored Dr. David S. McKay by naming an asteroid after him in 2002 (Asteroid Davemckay \#6111) in recognition of his pioneering work on lunar dust and the significant positive effects that his work on the Mars meteorite ALH84001 had on the development of planetary research. Dave's humility and humor is exhibited by his remarks after being notified of this honor: "It was an unexpected but very high honor to have an asteroid named after me. If it ever crashes into Earth, I will probably get the blame, but in the meantime it is very nice to have it out there orbiting the Sun for perhaps the next few billion years."

\title{
ACADEMICIAN GEORGY ALEXANDROVICH ZAVARZIN
}

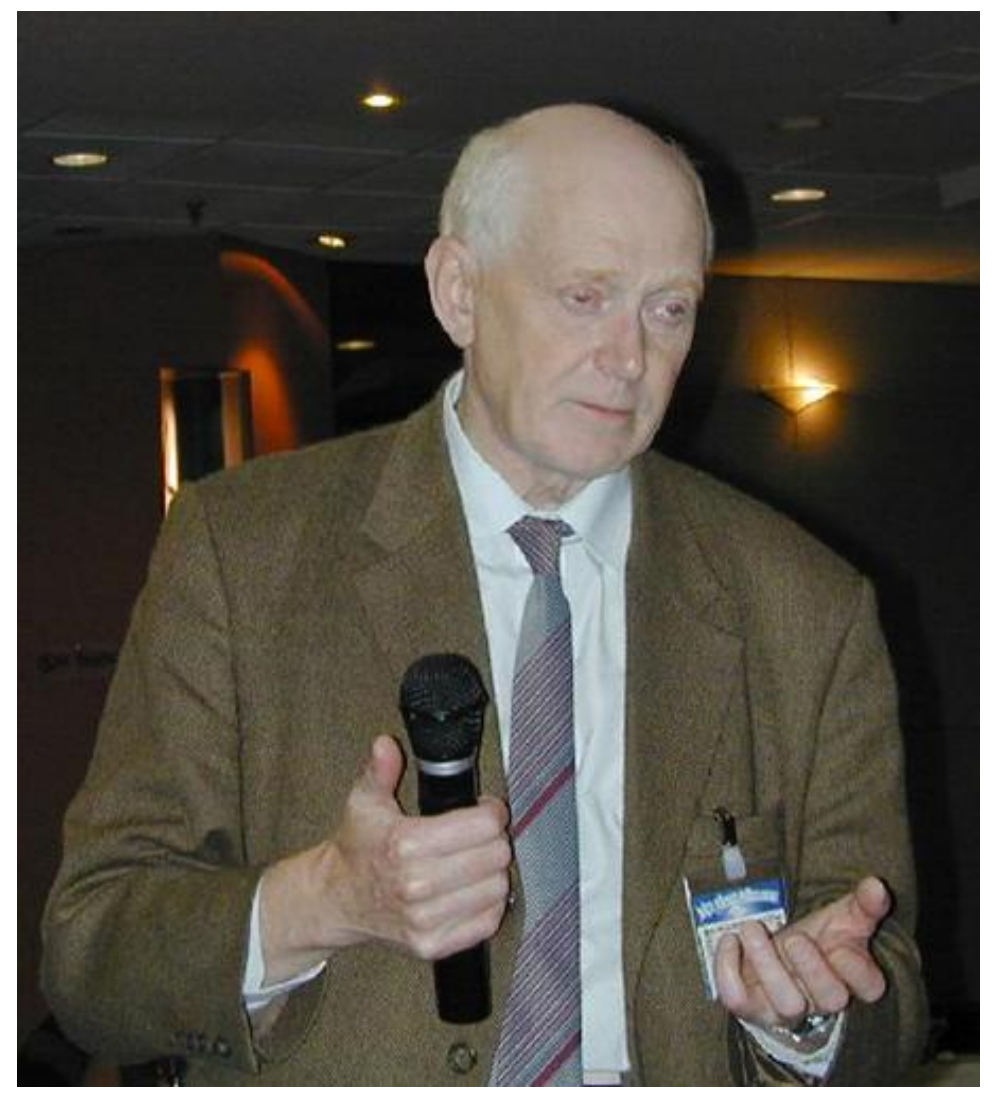

\author{
Dr. Georgy Alexandrovich Zavarzin \\ Academician, Prof. Moscow State University \\ January 28, 1933 -September 6, 2011
}


Georgy Alexandrovich Zavarzin was born on January 28, 1933 in St. Petersburg, Russia. He received his degree from the Moscow State University in 1955 (Biology of Soils Faculty) and his Ph.D. in 1958 with a thesis entitled "Agent of the second phase of the nitrification." Soon, he became Leader of the Department in the Institute of Microbiology of the Russian Academy of Sciences in 1961. In 1961, he described Blastobacter a new Genus of budding bacteria. ${ }^{22} \mathrm{He}$ completed his Doctoral Dissertation on "Chemoautotrophic microorganisms" at the Institute of Microbiology (RAS) in 1966. He was Professor at the Moscow State University and trained many of the finest microbiologists of the former Soviet Union. For thirty years, Georgy Zavarzin was Chair of the Department of "Microbial Communities - former name for Laboratory of Relic Microbial Communities" (1960-1990) INMI RAS. On December 23, 1976, he received the honored title Corresponding Member of Russian Academy of Sciences. Six years later he was Awarded the Order "Red Flag". In 1973, he was Awarded Laureate of Premium of Sergei Vinogradski by the Russian Academy of Sciences. In 1991 he was appointed to position of the Deputy Minister of Ministry of Nature, USSR and became a Professor Alumnus of the Moscow State University. On May 20, 1997, he was chosen on the highly respected title of Academician-Biologic Sciences of the Russian Academy of Sciences.

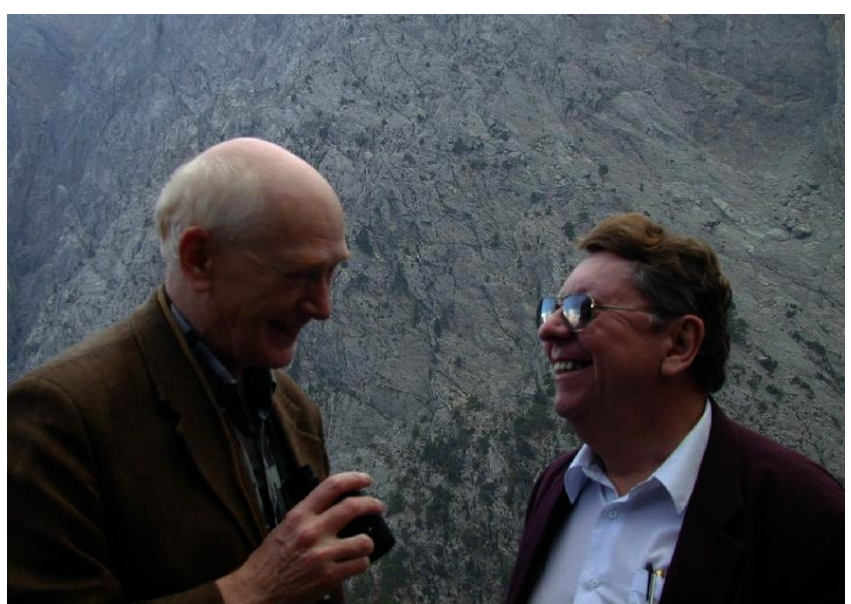

a.

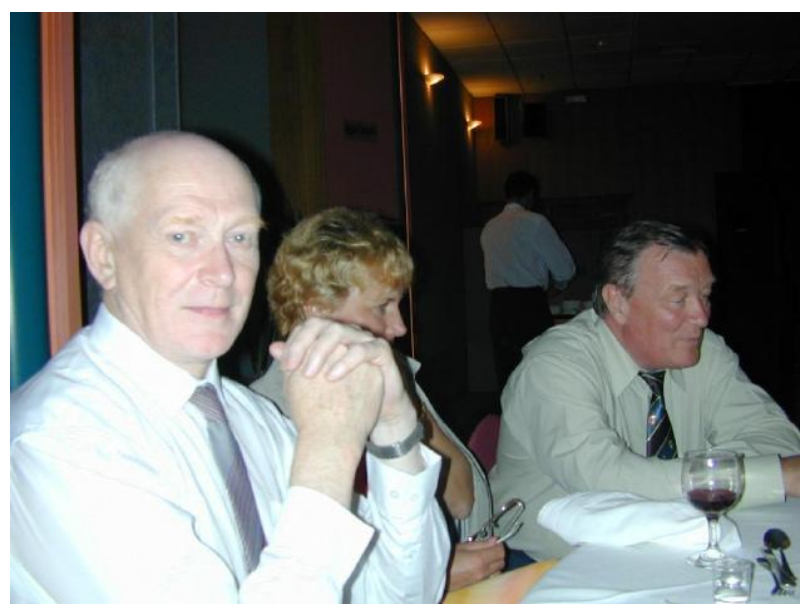

b.

Fig. 4. a. Academician Georgy Zavarzin with Richard B. Hoover (NASA/Marshall Space Flight Center) in Crete, Greece during the NATO Advanced Study Institute on Perspectives in Astrobiology ; b. Discussions with Academician Alexei Yu. Rozanov in Crete for the Conference on Origin and Evolution of the Biosphere. Photo: a. Prof. Roland Paepe and b. Richard B. Hoover

Academician Georgy A. Zavarzin is author of over 280 Scientific papers and books. He organized and played a major role in NATO International Advanced Study Institute on Astrobiology in Crete, Greece and in many scientific Conferences on Microbiology, Astrobiology and the Origin and Evolution of the Biosphere (Fig. 4).

His research in microbiology resulted in numerous major scientific discoveries and achievements:

- Systematic analysis of physical and chemical linkage of microorganisms and the environment

- Cyanobacterial communities and analysis of trophic chains and metabolic pathways

- Hydrogen bacteria as source of proteins

- Roles of microorganisms in the formation of the Earth's Atmosphere,

- Composition of Precambrian Biosphere

- Description of a new physiological group of CO-oxidizing microorganisms

- Characterization of novel microbiological processes: $\mathrm{H}_{2} \mathrm{~S}, \mathrm{CH}_{4}, \mathrm{CO}, \mathrm{Fe}^{2+} \mathrm{Fe}^{3+}$, and $\mathrm{Mn}$

- Description of communities of Hydrotherms, Psychrophiles, Hypersaline and Alkaline Lakes

- Cycle of basic chemical elements and the Origin and Evolution of the Biosphere

- Description of many new taxa on species, Genera and families level of Bacteria and Archaea

Academian Zavarzin's major works include:

- 1972-“Lithotrophic Microorganisms" 
- 1974-"Phenotypic Systematics of Bacteria -the Space of Logic Possibilities"

- 1978 - "Hydrogen and Carboxybacteria"

- 1984-"Bacteria and Composition of the Atmosphere"

- 1989 - "Calderic Microorganisms"- with coauthors

- 2001 - "Introduction to Environmental Microbiology"

- 2004 - "Courses of Environmental Microbiology"

- 2007 - "Biosphere Origin and Evolution" - with Dobretsov, Kolchanov and Rozanov (Eds).

- 2009 - Tri zhizni velikogo mikrobiologa. Dokumentalnaya povest o Sergee Nikolaeviche Vinogradskom (Three lives of the great microbiologist: Biographical Story of Sergei Nikolaevich Vinogradsky)

During his long and illustrious career Prof. Zavarzin served as Editor of several Scientific Journals including:

- 1977 - "Journal of General Biology"

- 1982 - "Nature"

- "Reports of Academy of Science"

- "Ecological Chemistry"

- "Current Microbiology"

Two bacterial genera: Zavarzinia compransoris (1994) and Zavarzinella (2009) were named after Academician Zavarzin who contributed to the understanding of this physiological group. ${ }^{24}$

\section{ACADEMICIAN ZAVARZIN AT WORK AND AT HOME}

Like many serious scientists, Georgy Alexandrovich Zavarzin work very hard all his life to contribute as much as possible to the field of microbiology. He authored many scientific volumes and popular science books, as well as textbooks and methodological manuals. He was well known and considered the leading microbiologist of the Soviet Union. He created a unique laboratory, which later was transformed into one of the Departments of the Institute of Microbiology at Russian Academy of Sciences. The subjects of his studies had covered all possible aspects of extremophilic microorganisms. (However, at that time, nobody referred to hyperthermophilic or psychrophilic bacteria as extremophiles). In his department, Georgy Zavarzin gathered excellent scientists who had received their scientific degrees and were working not just in the field of microbiology, but in molecular genetics, biochemistry and analytical chemistry. Everyone in his laboratory had a very busy schedule, and worked long hours and the publications and productivity within his department were at a very high level. There were always new and exciting results to present at International Conferences. All scientists working in his laboratories were very friendly and truly happy--often sharing funny jokes and new discoveries were gladly discussed at the coffee or tea-breaks. Birthday parties and PhD Thesis defense (on candidate or doctoral levels) were always supported and special events within the Department.

It was not a secret that behind of all of this happiness, productive work, and scientific creativity, the modest figure of Dr. Tatjana Zhilina was always standing by him. Working somewhat in his shade, she was always his best friend and supporter. She was an excellent scientists herself, and his lovely wife who gave birth to his two brilliant daughters. She simply adored him in all aspects of his life. Being an ex-ballerina, Tatiana had started work in one of his laboratories as a laborant. She passed her scientific career to the highest degree of the Doctoral PhD in microbiology, and she trained a number of her PhD students. Tanya, as Academician Zavarzin called her, is still an unexcelled and unsurpassed specialist in isolation and cultivation of methanogens and other difficult to cultivate bacteria.

Academician Georgy Zavarzin studied fossilized Precambrian cyanobacterial mats and compared them with modern, living, and in-situ samples that he studied. He also developed an experimental approach to the modeling of cyanobacterial mat structures. Later, he initiated his study of the fossilization of cyanobacteria and microfossils in astromaterials in collaboration with Alexei Rozanov, Stanislav Zhmur, Lyudmila Gerasimenko, Vladimir Gorlenko and Richard Hoover. As a result of this research, he established together with Academician Alexei Yuri Rozanov, the newly emerging field of research - Bacterial Paleontology. 


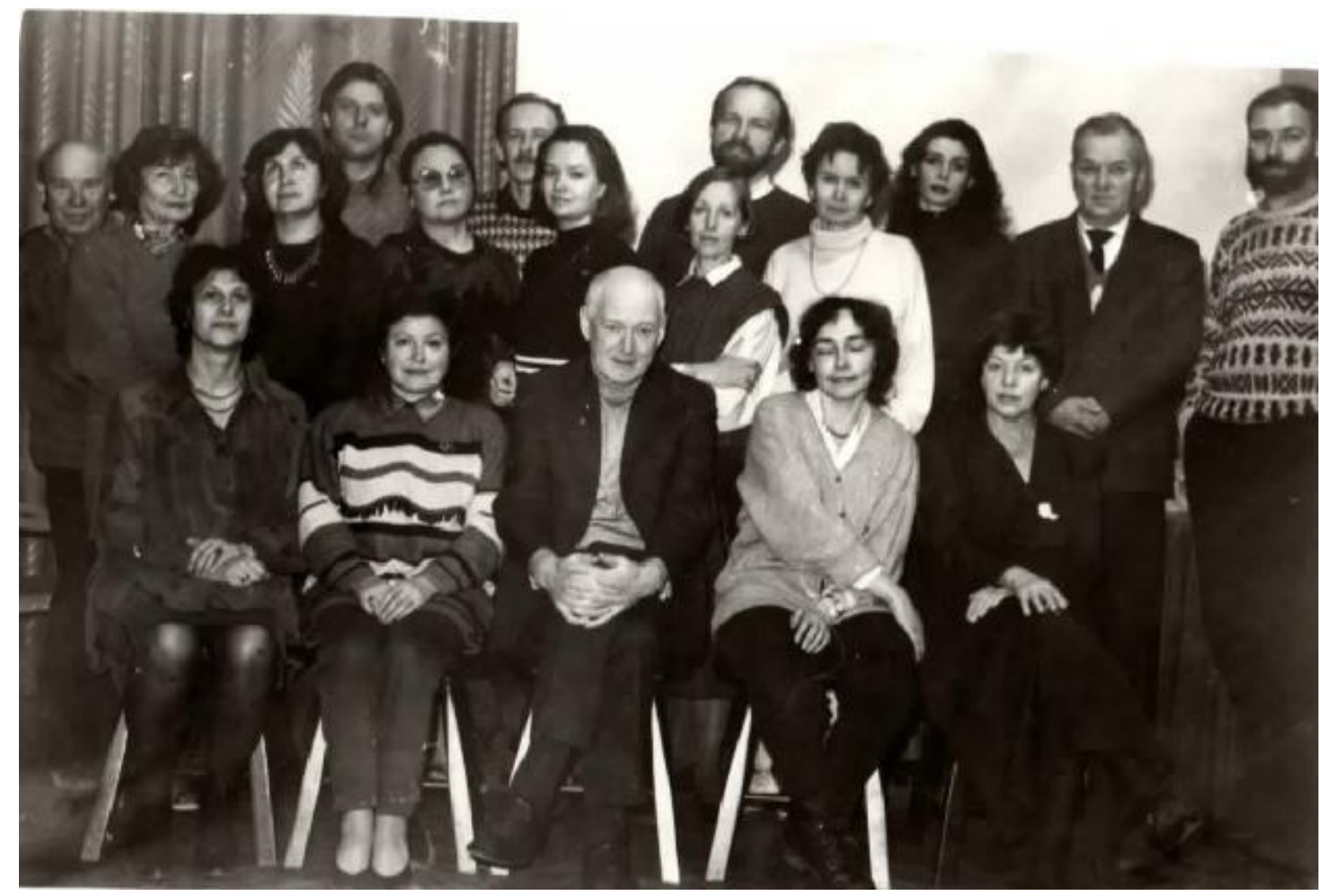

Fig. 5. Georgy Zavarzin with his scientists who worked in his Laboratories. Moscow, 1995.

Georgy Zavarzin's Department of Relic Microbial Communities included five laboratories covering the following major topics of the study of microbial extremophiles:

- Hyperthermophilic Archaea (Group headed by Dr. Lisa Bonch-Osmolovskaya)

- Psychrophilic Microorganisms (Group led by Dr. Alla Kostrikina)

- Cyanobacterial mats (Group of Dr. Lina Vasilieva)

- Halobacteria and Haloarchaea (Group of Dr. Tatiana Zhilina and Dr. Vadim Kevbrin)

- Problems of Microbial Acetogenesis (Group of Dr. Margarita Pusheva).

In addition, single individuals handled the research carried out within the department on:

Hydrogen bacteria (Dr. Nina Savelieva) and Iron-oxidizing bacteria (Valentina Balashova).

Everybody from his Department remembers how Academician Zavarzin had "inspected" the success of the work of his workers. Almost every morning he met his co-workers in a laboratory with the same question: "Are your cultures growing?"

After a positive answer, he always replied: "Thank God! Uh-huh!” He also communicated very easily with technicians, janitors and maintenance workers "How about our football team? Did you see them win? That was a very exciting game!" 

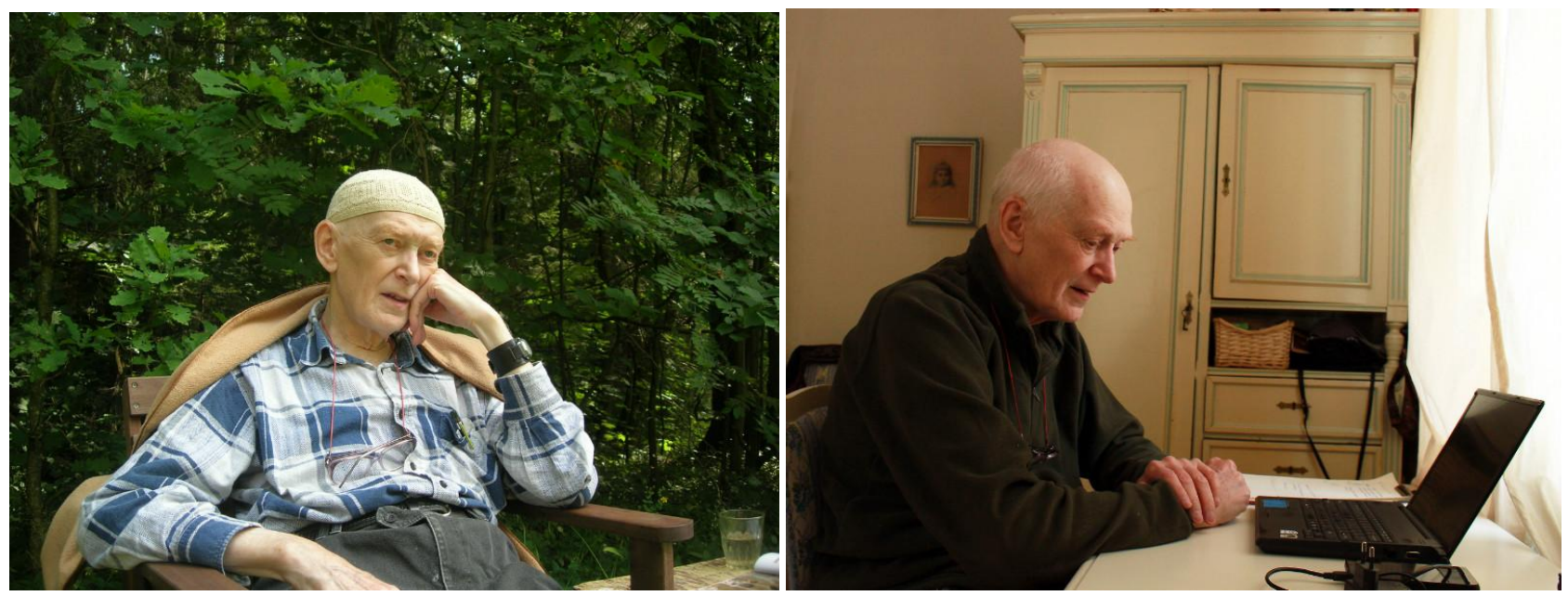

Fig. 6. Georgy Zavarzin at home - but always thinking and working.

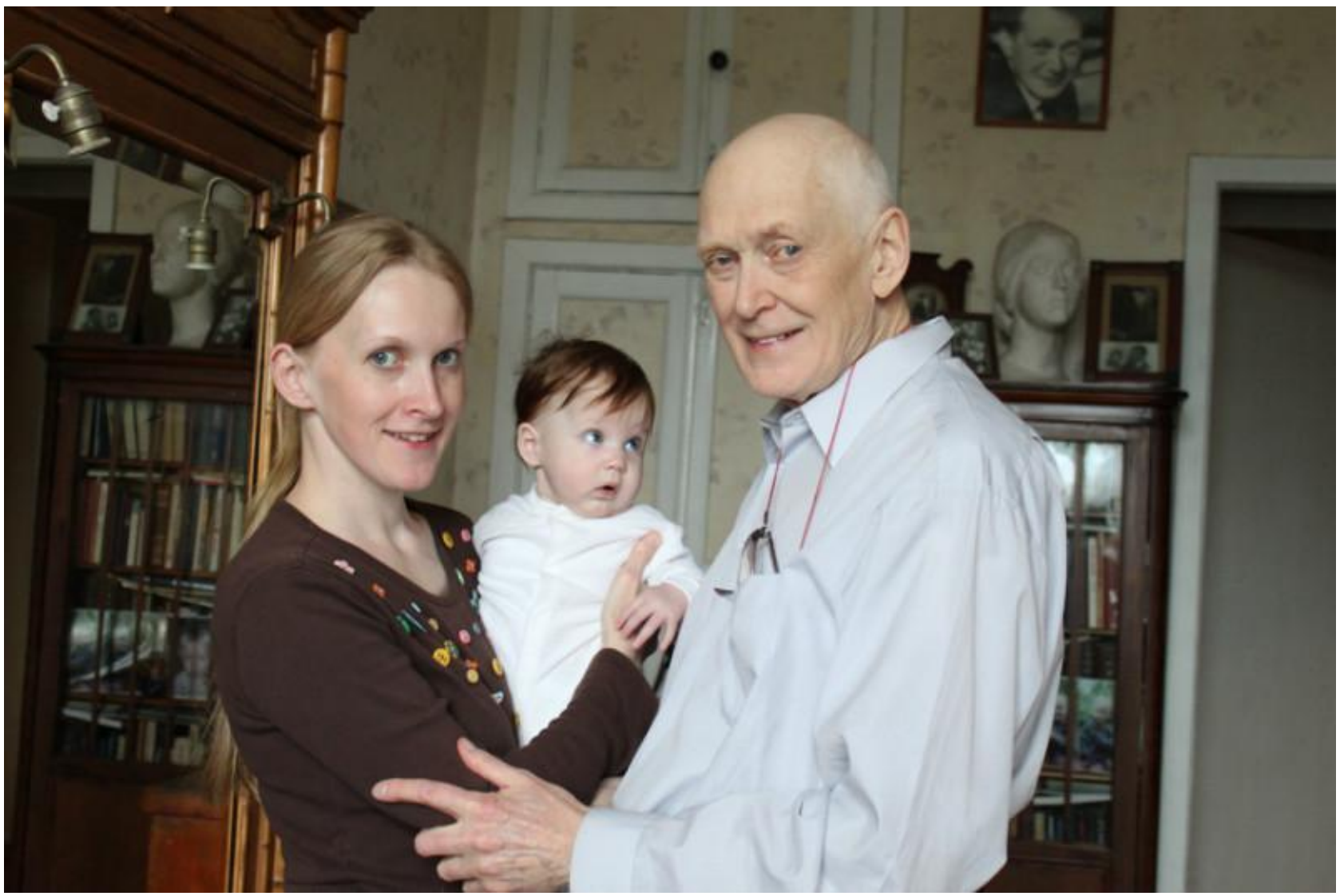

Fig. 7. Georgy Zavarzin with his daughter Anna and his youngest grandchild.

Proc. of SPIE Vol. $8865886502-10$ 


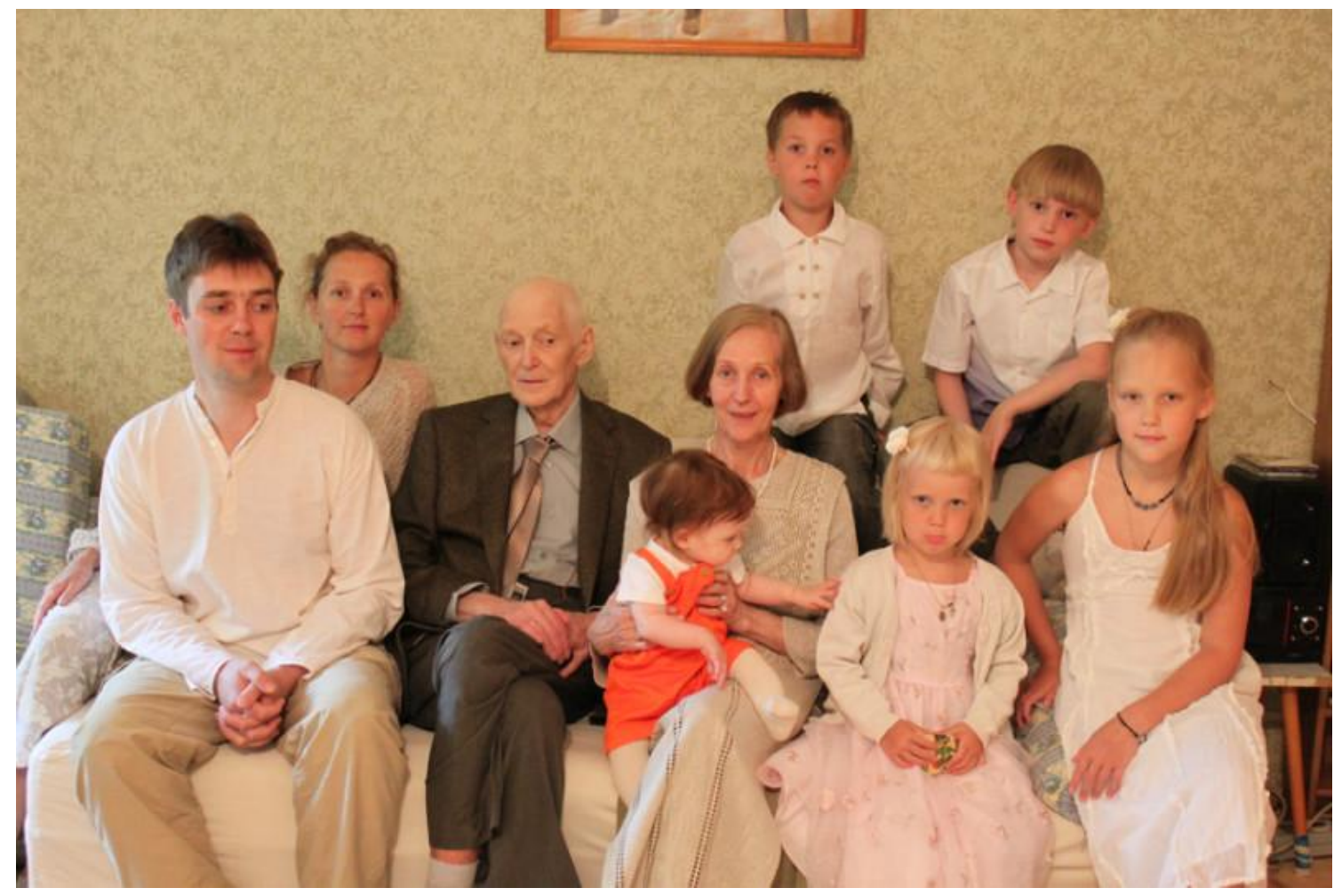

Fig. 8. Last year of life: Georgy Zavarzin with Tatiana and his family surrounded by his five grandchildren.

Georgy Alexandrovich Zavarzin made great effort to emphasize and communicate to the public the significance of the works of Russian aristocrat and greatest microbiologist of the last century Sergei Nikolaevich Vinogradski (a discoverer of Lithotrophy) whose name the Institute of Microbiology of Russian Academy presently carries. The book ${ }^{25}$ Georgy Zavarzin wrote about this magnificent and extraordinary person and scientist also shed light on the dark history of Soviet Science. It demonstrated the great brilliance and patriotism of Vinogradski, who declined the personal invitation of the world famous microbiologist Luis Pasteur to join him in Paris. Instead of accepting this great honor, Vinogradski returned to the service of his Tsar and fatherland knowing that academic conditions of Russia at that time were much poorer than those in Europe.

\section{Major Contributions of Academician Georgy A. Zavarzin to Science.}

During his long career, Academician Georgy A. Zavarzin made many important contributions to Science. Some of the major discoveries and achievements made in his laboratories are summarized here:

1) Study of Psychrophilic Ecosystems - Many new taxa were described on species and genera levels. The wide distributed of the populations of psychrophilic methanotrophic bacteria was discovered and a greater understanding was made concerning their role in the consumption of greenhouse gases to complete the biogeochemical cycle. Micobial degradation of cellulose in cold ecosystems was also studied and the results found practical application for biodegradation and purification systems of paper plants;

2) Bacterial acetogenesis was studied in different bacterial communities. Many new acetogens were discovered and characterized (many were distant from known species and represented novel genera. The work in the production of acetic acid was patented by Dr. Margarita Pusheva and applied in industry. 
3) Psychrophilic and mesophilic methanogens were described as many new species - particularly interesting were those from halo-alkaline natural ecosystems. The competition for hydrogen as an electron donor between lithotrophic sulfidogens and methanogens was analyzed in cold polar and halo-alkaline ecosystems.

4) Many novel halo-alkaliphiles (primary and secondary anaerobes) were described on species and genera levels, and several novel Families were created based on novel microorganisms; First representatives of alkaliphilic sulfate-reducing bacteria were isolated and characterized.

5) Hyperthermophiles from volcanic hydrotherms and hot springs were studied and many new taxa of Archaea and Eubacteria were isolated and described. Sulfur-reducers with complete metabolic oxidation were described. The most interesting discovery was - the description of new physiological group, CO-oxidizing anaerobes initiated in hyperthermophiles by Vitalyi Svetlichnyi and Tatiana Sokolova; The only thermophic species of the genus Spirochaeata, S. thermophila was isolated in Dr. Zavarzin's laboratory; Iron-reduction was investigated in thermophilic and mesophilic microbial communities, Alexandr Slobodkin described many new anaerobic species and genera of specialized ironreducing bacteria.

6) Dozens of species of Cyanobacteria from different extreme ecosystems were isolated (in algal-pure cultures) and characterized; Lyudmila Gerasimenko participated in study of the rapid fossilization of cyanobacteria in living systems and the evidence for microfossils of cyanobacteria the phosphorites of Khubsughul, Mongolia and other paleontological samples and carbonaceous meteorites.

7) Georgy Zavarzin was a pioneer in the application of an actualistic approach to a survey of relict microbial communities from hydrotherms, hypersaline lagoons, and soda lakes to field studies of the paleorecord in Precambrian rocks for the study of ancient terrestrial biospheres with possible relevance to astrobiology.

Dr. David Stewart McKay and Academician Georgy Alexandrovich Zavarzin were truly giants in their fields. They were an inspiration to a vast number of scientists all over the world. Their scientific contributions truly changed our understanding of planetary science and the geology of the Moon and Mars and expanded our knowledge of biomarkers, bacterial paleontology, microbial extremophiles, microbial diversity, the origin and evolution of the biosphere, the limits of life on Earth and the possibility of life elsewhere in the Cosmos. The world has lost two great scientists and pioneers of the modern field of Astrobiology. Dave McKay and Georgy Zavarzin were our dear friends and colleagues. They will be missed and always fondly

remembered by everyone who knew them and worked with them.

\section{ACKNOWLEDGMENTS}

We express our special gratitude for the photographs and good memories to all people who work with these magnificent scientists, and who will carry forward with many areas of research that draw from the knowledge gained in their important Astrobiology investigations and discoveries.

\section{REFERENCES}

[1] McKay, D. S., Gibson, Jr., E. K., Thomas-Keprta, K. L., Vali, H., Romanek, C. S., Clemett, S. J., Chillier, X. D. F., Maechling, C. R. and Zare, R. N. "Search for past life on Mars: Possible relic biogenic activity in Martian meteorite ALH84001." Science 273, 924-930 (1996).

[2] McKay D.S. and Heiken G.H. "Petrology and scanning electron microscope study of Apollo 17 orange and black glass". EOS Trans. AGU 54, 599-600 (1973).

[3] Meyer C., McKay D.S., Anderson D.H. and Butler P. "The source of sublimates on the Apollo 15 green and Apollo 17 orange glass samples." Proc. 6th Lunar Sci. Conf., 1673-1699 (1975).

[4] Heiken G.H., McKay D.S. and Brown R.W. "Lunar deposits of possible pyroclastic origin." Geochim. Cosmochim. Acta 38, 1703-1718 (1974).

[5] Heiken G.H. and McKay D.S. "Petrology of Apollo17 soils." Proc. 5th Lunar Sci. Conf., 843-860 (1974). 
[6] Heiken G.H. and McKay D.S. "A model for the eruption behavior of a volcanic vent in eastern Mare Serenitatis." Proc. 8th Lunar Planet. Sci. Conf., 3243-3255 (1977).

[7] Keller, L. P. and McKay, D. S. "Discovery of vapor deposits in the lunar regolith." Science 261, 1305-1307 (1993).

[8] Keller, L. P. and McKay, D. S. "The nature and origin of rims on lunar soil grains." Geochim. Cosmochim. Acta 61, 2331-2341 In 1993(1997).

[9] McKay, D. S., Fruland, R. M. and Heiken G. H., "Grain Size and Evolution of Lunar Soils" Proc. of 5th Lunar Conference, Supplement 5, Geochim. Cosmochim. Acta 1, 887-906 (1974).

[10] Cooper, B. L., McKay, D. S., Taylor, L. A., Wallace, W. T., James, J., Riofrio, L., and Gonzalez, C. P., "Lunar Airborne Dust Toxicity Hazard Assessments. Amer. Geophys. Union, Fall Meeting, Abstract P32A-08 (2009).

[11] Wallace, W.T., Taylor, L.A., Liu, Y., Cooper, B.L., McKay, D.S., Chen, B. and Jeevarajan, A.S. "Lunar Dust and Lunar Simulant Activation and Monitoring." Meteor. Planet. Sci., 44, 961-970 (2009).

[12] Wentworth, S.J., Keller, L.P, McKay, D.S., Morris, R.V., "Space weathering on the moon: patina on Apollo 17 samples 75075 and 76015" Meteoritics and Planetary Science, 34,593-603 (1999).

[13] Taylor, L.A., Pieters, C., Patchen, A., Taylor, D.H.S., Morris, R.V., Keller, L.P. and McKay, D.S. "Mineralogical and chemical characterization of lunar highland soils: Insights into the space weathering of soils on airless bodies." J. Geophys. Res, 115 (2010).

[14] Brown, I., Sarkisova, S., Garrison, D., Thomas-Keprta, K., Allen, C., Jones, J., Galindo, C. and McKay, D. "BioWeathering of Lunar and Martian Rocks by Cyanobacteria: A Resource for Moon and Mars Exploration." 39th Lunar \& Planet. Sci. Conf., 1673 (2008).

[15] Ciftcioglu, N. and McKay, D.S. (2010). "Pathological Calcification and Replicating Calcifying-Nanoparticles: General Approach and Correlation." Pediatric Research, 67, 490-499 (2010).

[16] McKay, D. S., Rozanov, A. Yu. Hoover, R. B. and Westall. F. M., "Phosphate biomineralization of Cambrian Microorganisms" Instruments, Methods and Missions for Astrobiology, (R. B. Hoover, Ed.), Proc. SPIE 3441, 170-177, (1998).

[17] Thomas-Keprta, K. L., Bazylinski, D. A., Kirschvink, J. L., Clemett, S. J., McKay, D. S., Wentworth, S. J., Vali, H., Gibson, E. K., Jr., and Romanek, C. S. "Elongated prismatic magnetite crystals in ALH84001 carbonate globules: Potential Martian magnetofossils." Geochim. Cosmochim. Acta 64, 4049-4081 (2000).

[18] Thomas-Keprta K.L., Clemett S.J., Bazylinski D.A., Kirschvink J.L., McKay D.S., Wentworth S.J.,Vali H., Gibson, Jr. E.K., McKay M.F., Romanek C.S. "Truncated hexaoctahedral magnetite crystals in ALH84001: presumptive biosignatures." Proceedings of the National Academy of Science 98, 2164-2169 (2001).

[19] Thomas-Keprta, K., Clemett, S., McKay, D., Gibson, E., \& Wentworth, S. (2009). "Origins of magnetite nanocrystals in Martian meteorite ALH84001." Geochimica et Cosmochimica Acta, 73, 6631-6677 (2009).

[20] Friedmann, E. Imre, Wierzchos, J., Ascaso, C. and Winklhofer, M., "Chains of magnetite crystals in the meteorite ALH84001: Evidence of biological origin." Proceedings of the National Academy of Science 98, 2176-2181 (2001).

[21] McKay, D.S., Thomas-Keprta, K.L., Clemett, S.J., Gibson Jr, E.K., Spencer, L. and Wentworth, S.J. "Life on Mars: new evidence from martian meteorites." Instruments and Methods for Astrobiology and Planetary Missions XII, (R. B. Hoover, K. D. Retherford, G. V. Levin and A. Yu. Rozanov, Eds.), Proc. SPIE 7441, 744102, (2009).

[22] Zavarzin, G. A. "Budding bacteria." Mikrobiologiya 30, 952-975, (1961).

[23] Zhilina, T. N., Zavarzina, D. G., Panteleeva, A. N., Osipov, G. A., Kostrikina, N. A., Tourova, T. P. and Zavarzin, G. A., " Fuchsiella alkaliacetigena gen. nov., sp. nov., an alkaliphilic, lithoautotrophic homoacetogen from a soda lake." Int J Syst Evol Microbiol. 59, 357-364 (2009).

[24] Kulichevskaya, I. S., Baulina, O. I., Bodelier, P. L. E., Rijpstra, W. I. C., Damste, J. S. and Dedysh, S. N. "Zavarzinella formosa gen. nov., sp. nov., a novel stalked, Gemmata-like planctomycete from a Siberian peat bog." Int J Syst Evol Microbiol. 62, 1666-1673, (2012). 